International Journal of Zakat 1(1) 2016 page 64-77

\title{
Philanthropy in Practice: Role of Zakat in the Realization of Justice and Economic Growth
}

\author{
Bilal Ahmad Malik
}

Centre of Central Asian Studies, University of Kashmir

\begin{abstract}
The entire economic scheme developed under the guiding principles of Shari'ah (Islamic Law) envisages an internally balanced system of economy that neither accepts capitalism nor communism in totality. According to the laws, the realization of justice ( $a$ 'dl) and wellbeing (falah), i.e., the means to seek blessings of God (fadhl al-Allah), determines its principal objectives (maqasid). Nevertheless, the economic structures adopted by the contemporary Muslim societies, in general, are incoherent with the economic philosophy of Islam. They are practically disconnected from the mechanics and efficiency of Islam's equity instruments and philanthropic institutions. Consequently, as per Marx's class conflict theory, economic inequality has spread its roots and traumatized the dynamics of participatory economics, distributive justice, and social equality. Factors such as non-inclusive economics, exploitation as a market principle, and concentration of wealth in few pockets have completely transformed Muslim economies into "capitalist" ones. After conducting critical researches vis-à-vis this paradigm shift in the Muslim world, highbrow Muslim intellectuals have reached to this point that alongside with interest-based means of financial intermediation, non-functionality of philanthropic institutions such zakat and baitulmal has practically divided the society into privileged and deprived classes. The economic advantage of "privileged class" over "deprived class" has become one of the major stumbling blocks in the way of achieving welfare and social justice. Under such vulnerable conditions, it is being argued that "reinstitutionalization" of zakat, both at civil society and state level, is the means to provide socio-economic insurance to those who are otherwise neglected. By facilitating the "constructive channelization" of wealth from "privileged class" to "deprived class", institution of zakat has the potentiality to overcome the problems like relative deprivation, poverty, illiteracy, unemployment, and so on. In this context, giving of zakat must not be seen merely as a religious obligation; on the contrary, it must be examined in relation to its socioeconomic effects. The present research is an attempt to answer the question regarding how reinstitutionalization of zakat can help in the minimization of poverty rate and promotion of socio-economic justice in contemporary "unbalanced" Muslim societies.
\end{abstract}

Keywords: Islamic Economics, Zakat, Social Justice, Poverty, Economic Growth

\section{INTRODUCTION}

Social justice and economic growth are correlative terms. The material development of any human society is impossible until it has a strong and sustainable economy that, in turn, is strongly rooted in the concept of social justice. It is generally observed that poor and destitute people fall easy prey to social evils that, in turn, leads to the reduction of gross productivity and decline in overall economic development. Some of the major social malfunctions resulting from an unstable economic structure, devoid of inclusive participation, equity distribution, and social justice have been identified: illiteracy, moral bankruptcy, increase in crime rate, violence, and weak health 
profile (Abdullah \& Suhaib 2011; Hasan 2007; Dhar 2013).

The religion of Islam, being an "all-encompassing" system of values and codifications, has addressed the issue of economic instability and its adverse consequences by placing considerable emphasis on the rich to spend their wealth, out of love ('ala hubihee), for the cause of the collective wellbeing of society. To realize this objective, Islam promotes the philosophy of cooperation, sharing, and distributive justice. The fundamental principle laid down in the Quran in this direction is that, "wealth should not circulate only among the rich' (59:7). Since the day of its inception, Islam has unequivocally nullified all humanly produced inequalities in the distribution scheme of material resources. However, it does not fully affirm Mark's philosophy of communism that entails the undue distribution of wealth based on theory of equality rather than equity (Mawdudi, 1975; Muslehuddin 2009). The key underpinnings of Islam vis-à-vis minimizing inequalities, and not necessarily eliminating them, are fundamentally anticipated to promote the culture of "social cohesion" and "creative cooperation" whereby all members of the society enjoy rights, justice, and avenues of entrepreneurship. Thus, Islam advocates the "philanthropy of practice" and amplifies the meaning and scope of justice, growth, and sustainable development while keeping the honor, value, and centrality of human life in view. ${ }^{1}$

Islam has established different financial institutions such as baitulmal, ushur, sadaqah, and zakah to ensure the circulation of wealth across all social stratifications, irrespective of caste, colour,

\footnotetext{
1 To my understanding, the honour and value of human life is central to philosophy of creation in Islam. It can be understood through God's claim of calling man ahsani taqweem (best of all creations) and also through the philosophy of takreem. The philosophy of takreem is rooted in the Quranic verse which mentions that God has honoured sons of Adam (la qad karrumna bani adam) irrespective of their religious belongings.
}

or religious affiliation. Thus, right from the Prophetic period, the institution of zakat has been instrumental in the economic transformation of Muslim ummah; however, it is unfortunate that for almost one century, when most of Muslim lands were enslaved under colonial establishments, the collection and distribution of zakat funds remained abandoned from its institutionalized framework. Since then, the entire administration of zakat got decentralized and its dues become mere voluntary depending upon the piety of an individual, who give or not give. The malfunctioning of zakat institutions brought negative implications such as poverty, illiteracy, economic injustice and under development throughout the Muslim world. Given the nature of economic vulnerability in contemporary Muslim societies, it becomes imperative to revive the institutionalization of zakat in order to create a supportive environment for the realization of social justice, economic growth, and minimization of poverty ratio.

\section{LITERATURE REVIEW}

The quantum of literature that has been produced to date on the historical development, juristic requirements, and multi-dimensional applicability of zakat can be broadly classified under two categories. Literature that falls under the first category deals with the specific juristic issues pertaining to zakat called as fiqh ul-zakat. Such literature is mostly contributed by classical fuqaha (Islamic Jurists) and also some contemporary Muslim economists. This literature primarily pertains to the meaning, philosophy, rulings, and juristic management of zakat. Among the contemporary scholars, Qaradawi (1999) has academically summarized most of the contemporary issues related to zakat rulings in his magnum opus Fiqh al-zakat. Kahf (1997), a prominent theoretical economist, has extensively covered issues on zakat management using cross-country 
data from Saudi Arabia, Malaysia, Libya, Pakistan, and Sudan. The second category of literature deals with the economics and financial effectiveness of zakat. According to Kahf (1997), this literature is mostly comprised of works covering the impact of zakat on economic aggregates namely consumption, investment, and supply; the relationship between zakat and macroeconomic models; socio-economic role of zakat and finally the similarities and dissimilarities between zakat and taxation or other conventional social security systems. Without going into detailed descriptions vis-à-vis categorization of zakat literature, I will directly come to the point about how contemporary literature has evaluated the significance and applicability of zakat institutions, while examining different cases studies.

The practice of zakat is basically a monetary devotion. According to Siddiqi (1996), zakat is based on the concept that all material things belong to Allah (God), and wealth, therefore, is positioned at the disposal of mankind as an amaanh (trust). The obligation of zakat is mandatory on every Muslim who possesses the minimum nisaab (exemption limit or criterion of zakatability) of wealth that enjoys growth or is a result of a growth process (Qaradawi, 1999). The reason for mandating nisaab is to ensure that none is forced to give zakat out of what he or she does not have and that no wealth goes without zakat (Kahf, 1989; Ashaari \& Mohamed, 1989; Ausaf \& Azeem, 2011; Muslehuddin, 2009). The modern approach to the zakat institution emphasizes that it is an economic and social instrument that could bring economic stability and security at large (Dhar, 2013; Yusoff, 2008; Ibrahim, 2015). The payment of zakat not only establishes a direct link between the welloff and economically marginalized but also provides a practical mechanism in contributing towards lessening the borders of inequality (Bremer, 2013; Desumite \& Yousuf, 2010; Rahim, 2003; Yusoff,
2008). The Islamic concept of social justice and economic development would not be meaningful unless accompanied by economic justice so that everyone gets his/her due for his/her contribution to society and that there is no exploitation of one individual by another. Therefore, Islam demands that all the resources at the disposal of human beings must be utilized efficiently and equitably to fulfill the needs of all and to bring about an equitable distribution of income and wealth (Ansari, 2011; Siddiqi, 1996; Muslehuddin, 2009).

On the basis of different case studies conducted by Abdullahi (1991) in Indonesia, Khan (1993) in Pakistan, Faridi (1995) in India, Ajeel (1995) in Kuwait, Abdul Wahab (1995) in Malaysia, Azharuddin (1988) in Bangladesh, Balogun (1999) in Nigeria, Dogarawa (2009) in Ghana, and many others, it has been proposed that the institution of zakat serves as a unique philanthropic mechanism that promotes participatory economic development. Ibrahim (2015), while examining the role of zakat in contemporary Muslim societies, concludes that zakat should be institutionalized under state patronage in the case of mainstream Muslim geographies and by civil society organizations and religious communities in the case of minority situations. Bremer (2013) takes the case of Egypt and suggests that zakat is evolving as a longterm development program that advocates engaging the poor as partners rather than a static charity model. He underlines the need to initiate more systematic efforts regarding the application of zakat while taking into consideration the rapidly changing global economics. In their joint study, Desumite and Yusoff (2013) highlighted the role of systematic management of zakat collection and distribution and, eventually, its contribution towards improving the wellbeing of the people in the Federal Territory of Malaysia. Kusuma and Sukmana (2010), in their joint work, suggested that role of zakat in tackling poverty, especially in the Muslim world, is very relevant and 
of contemporary importance, provided the means to collect and disburse funds are effectively developed. They also highlighted the role of the state in making the institution of zakat as an element of economic growth and social justice. Hoque, Khan, and Mohammad (2015) investigated the cause of poverty in Muslim countries, the effectiveness of zakat management institutions, the mode of zakat distribution, and the necessity for an entrepreneurial framework. In their concluding remarks, they maintain that poverty is not due to lack of resources only, rather in most cases it is due to lack of participation and entrepreneurship. Therefore, introducing entrepreneurship development programs through institution of zakat could be used as means to promote economic growth. Mohsin (2013) studied role of zakat in eradicating the riba (interest) and poverty while making a case study of Salary Deduction Scheme of Malaysia. He observes that the current practice of the collection of zakat from monthly salary in Malaysia provides evidences that zakat has huge impact on the reduction of total poverty. Dhar (2013) takes the case of zakat from an accountant's viewpoint and proposes that zakat is a measure of social justice in Islamic finance. Most of the literature that has been consulted and reviewed for the preparation of this paper almost unanimously suggest that until the institution of zakat is revived, the fundamental objectives of Shari'ah such as justice $\left(a^{\prime} d l\right)$ and wellbeing (falah) cannot be realized in the absolute sense.

\section{ZAKAT ${ }^{2}$ : GENESIS AND CONTEMPORARY ATTITUDE}

\footnotetext{
${ }^{2}$ In Arabic linguistics, zakat is the infinite of the verb zakaa, meaning, "to grow, to purify and to increase ${ }^{e e}$. In the Islamic law, the word zakat refers to the determined share of wealth prescribed by Allah to be distributed among the categories of those entitled to receive it. It is a compulsory payment by the wealthy to the economically underprivileged (Mathews and Tlemsani, 2003).
}

In the formative years of Islam, zakat was just a moral obligation for any legal verdict had not come yet. However, after the Prophet's migration to Madinah and development of Islam as a state religion, zakat was declared a compulsory religious obligation. Eventually, zakat developed as a systematic socio-economic program to meet the basic needs of local Muslims (Denny, 2005, p. 115; Benthall, 1999; Hamidullah, 1993, p. 234). The legal requirement for giving zakat is that the sum, above the minimum expenditure, remaining for a whole year with the owner becomes liable to a charge of two and half per cent $(2.5$ percent). This small percentage will go towards meeting the social welfare needs, as stated in the key Quranic verse about zakat:

"The zakat is only for the poor and needy, those who work to collect them, those whose hearts are to be won, the ransoming of slaves, debtors, in Allah's way[for good works like scholarship, missionary projects, charitable, cultural, and educational institutions] and the wayfarer.” (Quran 9:60)

Maintaining the obligatory nature of zakat, the Quran at other place orders the Prophet:

"Of their goods (wealth), take alms, that so thou mightiest purify and sanctify them; and pray on their behalf. Verily thy prayers are a source of security for them: And Allah is One Who hear and know." (Quran 9:103)

While responding to authoritative injunctions of Quran vis-à-vis zakat, the Prophet during his glorious tenure (khair al-kuroon) appointed zakat workers (a'ameleen) to collect zakat and assigned 
to them some income from zakat proceeds. It was the first initiative to institutionalize zakat funds that has happen under the supervision of the Prophet himself. It is reported that once a person questioned the Prophet (peace be upon him) about the legality of zakat that whether it is to be paid through a zakat collector or not. To this, the Prophet replied as follows:

"Yes, if you give it to my
messenger, you are freed
from that obligation as far
as Allah and His Messenger
are concerned. You deserve
its reward, and if it is
tampered with later, the sin
is on whoever changes it."
(Musnad Ahmad bin
Hanbal, Kitab al-zakat)

During the Prophet's time, these zakat officials were required to approach potential zakat payers, and after having properly calculated their assets, collect the due amounts. The application of this method was evident regarding collection of zakat on visible wealth, that is, livestock and agriculture. For other zakatable properties, different rates were set for the calculation of the zakat due. For example, money, gold, and silver were taxed at the rate of two and half percent per annum and the agricultural produce was taxed at the rate of ten percent. It is worth mentioning that at agricultural produce the rate of zakat is not uniform since it varies according to the nature of irrigation used (Qaradawi, 1999; Denny, 2005; Hamidullah, 1993). The categories of properties liable for zakat are as follows:

- Cash, gold and silver;

- Merchandise used in trade (but not personal possessions used in ordinary living, like automobiles, clothing, house and jewelry);

- Mineral extracted from the ground;

- Ancient treasure;

- Cattle;

- Crops from tilled land.
After the Prophet's death, Abu Bakr, first caliph of Islam continued the Prophetic legacy. He retained most of the zakat collectors who were appointed during the time of the Prophet. The importance of giving zakat in the early Islamic society could be understood from the famous statement of Abu Bakr made against those who refused to give zakat. He equated refusal of zakat with disbelief (kufr). The historical words of Abu Bakr are as follows:

"If they withhold giving (as zakat) even a (little) rein of a camel or a small baby sheep (that is due on them) I will fight them for it. Zakat is the due obligation on properties. By God I will fight whoever discriminate between prayers and zakat" (Ibn kathir 1997, V, 9, pp. 437-39)

Abu Bakr ruled for a short period of two years; therefore, he was not able to introduce any kind of reformation in general. However, Umar, the second caliph of Islam, introduced the mechanism of al'ashir for collecting zakat on merchandise, especially from Muslim traders who were returning from other countries at check points on major highways. This tradition of collecting zakat and distributing it within the Shari'ah requirements under the supervision of state continued till the fall of the Ottoman Empire in 1924 (Kahf, 1989; Qaradawi, 1999; Ahmad, 2004; Mohsin, 2013; Dhar, 2015).

However, the Muslim world had lost its intellectual, academic, and political glory long before 1924 and its decline had begun right form the days of the fall of Baghdad in 1258. However, after the breakdown of nominal unity on the name of Ottoman Empire (Khilafati Uthmania) at the hands of Kemal Atatürk, most of the mainstream Muslim lands fell under the direct influence of colonial powers. Consequently, these colonized Muslims 
started to imbibe the cultural traits of the dominant culture. Secular elites such as Jammal Abdul Nassir (Egypt), Kamal Kemal (Turkey), and Reza Shah Pahlavi (Iran) drastically replaced the "older" values of society with "new" imported structures. As a result, Islam remained merely a "ritualistic" tendency rather than a source of practical guidance (Hourani, 2005, p. 345-6). The introduction of liberal and secular values, replacing the traditional ethos, largely abjured the Islamic way of life, and the institution of zakat met with the same fate. (Al-Sheikh, 1995; Benthall, 1999; Hamidullah, 1993; Bremer, 2004; Ahmed, 2004). The following are the words of Qaradawi:

"were it not for the concern
of some Muslim individuals
and institutions, zakat
would have been completely
eradicated from Muslim
life" (Al Sheikh 1995, p.
368).

After the end of colonial era, serious concerns about such forcibly imposed cultural transformations began to arise within the Muslim societies. While responding to "new" structures such as modernization, secularization, and Westernization, Muslim intellectuals got actively engaged in strengthening their religion as a mark of their cultural identity. Dekmejian writes:

"In the opinion of revivalist
intellectuals, the very
integrity of the Islamic
culture and way of life is
threatened by non-Islamic
forces of secularism and
modernity, encouraged by
Muslim governments."
(Dekmejian 1988, p. 10-
11).

Today, as a result of that parallel process, many mainstream Muslim countries such as Pakistan, Sudan, Malaysia, Saudi Arabia, Kuwait, Libya,
Jordan and Iran have established centralized zakat collection departments approved by the their respective governments. Countries such as Pakistan and Saudi Arabia have also developed innovative techniques concerning the coverage and rates of zakat (Ahmed, 2004; Azzam, Iqbal \& Tayyab, 2014; Kuran, 2004). For example, they have extended the obligation of zakat to working companies on the basis that companies are juristic persons and have also imposed a flat zakat levy on certain types of deposits. In the case of Saudi Arabia, the rates of zakat levy imposed on imports vary from commodity to commodity, and in Pakistan, the rates of zakat levied on all farm outputs is at the rate of 5 percent, irrespective of the mode of irrigation applied (Ahmed, 2004; Azzam, Iqbal \& Tayyab, 2014).

\section{SOCIO-ECONOMIC RELEVANCE OF ZAKAT}

Islam explicitly explains the principles of justice, concept of halal (legal) and haram (illegal), role of individual and state regarding utilization and allocation of resources. It seeks to protect both individual and society from all odds of man's exploitative behavior. In this context, zakat is a religiously motivated economic instrument through which the surplus wealth of society is taken out to satisfy the essential needs and encourage entrepreneurial behavior among those who are not fortunate enough to have wealth of their own. Unlike other philanthropic associations, the Quran declares zakat as due right of "have not's" by saying, "wa fi amwalikum haqqus saa'ileena wal mahroom," which means that in your wealth there is right of those who ask and those who do not have wealth at all. Thus, the Quran makes a fundamental difference between "charity for the sake of charity" and "charity for the sake of duty". It recognizes zakat as an institution that has the inbuilt capacity to directly or indirectly influence economic activity and its effects 
on different social variables and also determines the direction along which the overall economy should move. It performs some of the major functions of modern public finance that deals with social security entitlements, social assistance grants for childcare, food subsidy, education, health care, housing, and public transportation in a welfare state. Similarly, it mitigates social inequalities incurred as result of exploitative economic behavior of man and covers the areas of social justice and social security (Shehata, 1989; Qaradawi, 1999; Yusoff, 2008; Mohsin, 2013). In the next section, I will outline how zakat as a practical philanthropic act can be applied to address some major socio-economic problems such as poverty alleviation, unequal distribution, weak economic growth, and beggary.

\section{POVERTY ALLEVIATION}

The theories and definitions regarding poverty explain that it is a condition to prompt injustice, social disequilibrium, and deprivation of wellbeing. Today, the Muslim population is rising from 1.6 billion in 2010 and is expected to reach 2.2 billion by the end of 2030 (Pew Research Centre, 2014). Despite holding 70 percent of the world energy resources, 40 percent of natural resources (Laghari, 2013), with strategic geographical location (Hoque et al. 2013), Muslim societies are still the world's poorest nations. At present, out of 1.7 billion world's poor, 44 percent (The Nation 2011) or 35 percent (World Bank 2010) are residing in Muslim countries. Nevertheless, developmental economists have produced different models such as Harrod-Domar Growth Model, Lewis Structural Change Model, and Rostow's Model to uplift poor nations on the path of economic development; however, unfortunately, most of these theories failed to achieve the expected results. According to economic pundits, under such vulnerable conditions "pro-poor growth" mechanism, entailing the poor's access to financial services and other developmental and management activities is the only possible solution to reduce the level of poverty. In this regard, international agencies such as the World Bank and International Monetary Fund (IMF) have been found to be engaged with different levels of developmental projects throughout the world, especially in developing countries of Africa and Asia.

To make this world a "povertyfree" place to live, alongside with purely financial agencies, religious associations are also found actively engaged with their philanthropic projects. Muslim nations, who cannot remain uninvolved, are also seen busy in the fight against the menace of poverty. Muslim economists and scholars are of the opinion that zakat is the best "pro-poor growth" model that would have the maximum effect on poverty, provided it is allocated on the basis of the poverty rate and the quality of economic policy (Hairunnizam \& Radiah, 2010; Mikami and Inoguchi, 2008; Riaz, 2007; Yusoff, 2008; Bello, 2009; Hassan, 2010; Fuadah et al., 2013). In both situations, Muslims living in independent countries and those Muslims living under democratic and secular constitutions such as India, zakat institutions and zakat development funds could be established to overcome the problem of poverty. It is quite fascinating that different research findings show that 15 out of 37 Muslim economies (OIC member countries) require only a small amount of resources for poverty alleviation and that is easily possible through the revival of zakat institutions (Shirazi \& Amin, 2006). I propose, that if Shari'ah experts, scholars and economists would collectively develop a framework, applicable throughout Islamic world such as Islamic Development Bank (IDB), for constructive utilization of zakat proceeds, then it would be not be too late to experience "povertyfree" Muslim zones. This framework must include providing education to beneficiaries, vocational training, necessary industrial and agricultural tools, simple fixed assets for small utility and 
trade projects working capital to craftsmen, and low-cost housing and medical facilities (Shehata, 1989; Dogarawa, 2008).

\section{REDISTRIBUTION OF WEALTH}

The failure of the "Trickle Down" economic model in contemporary economics has put the development economists on toes as wealth remained stuck to its original investor, which otherwise was expected to flow to bottom line of the society.

Researchers have assessed that when the richest, 20 percent of the society, increase their income by 1 percentage point, the annual rate of growth shrinks by nearly 0.1 percent within five years (IMF, 2015). From this, Marks's "class conflict" theory is justified as this theory is primarily rooted in the dissatisfaction of individuals with the scheme of distribution where one gets heavily benefited and other heavily exploited. As mentioned earlier, Islam does not acknowledge undue inequalities in the distribution of material resources. Therefore, it has introduced zakat as "pro-poor" instruments to reduce these inequalities up to the mark of socioeconomic stability, if not to eliminate them in totality. The institution of zakat promotes "growth oriented" circulation of wealth. It seeks redistribution of wealth from the "point of concentration" to "point of scarcity". Thus, in an Islamic economic system, the institution of zakat incorporates proper balance between the extremes of capitalism and communism (Hairunnizam \& Radiah, 2010; Benthall 1999; Mawdudi 1975). This is supported by the following Quranic verse, which says the following:

"This (wealth) may not circulate solely among the rich from among you" (Quran 59:7)

In her research, Patmawati (2006), admits this fact and maintains that "zakat is the most effective redistribution of wealth, which does not only ensure social justice in the society but also mobilizes and makes resources available for the poor". By facilitating growth avenues to deprived class of the society, zakat actually improves the capacity of collective production of the Muslim community and facilitates "class harmony" by inculcating a sense of belongingness among all members of the society (Muhammad et. al 2013).

\section{PROMOTION OF ECONOMIC JUSTICE}

The main concern of economic justice ( $a d l$ al-ma'ash), according to Islam, is to ensure socio-economic stability and establish a welfare society wherein the principle of 'No-Injury' (la dhar) could flourish up to its maximum (Siddiqi, 1996; Chapra, 2008; Khudduri, 1984). The principle of 'No-Injury', bound to its nature, cannot be materialized unless the entire structure of production, consumption, distribution, and exchange of wealth follow the scheme of justice envisaged under Islamic law (Shari'ah). In this regard, zakat has been identified as a core component of Islamic economic philosophy that would enable it to establish social justice, which broadly involves economic justice and maintenance of social cohesion (Patmawati, 2006; Hassan, 2007; Bello, 2009; Suhaili and Nur Azzah, 2009). This assertion is established in the following Quranic verse:

"The believers, men and women, are protectors one of another: they enjoin what is just, and forbid what is evil: they observe regular prayers, pay zakat, and obey Allah and His Messenger. On them will Allah pour His mercy: for Allah is Exalted in power, Wise". (Quran 9:71) 
From the above Quranic verse, it is evident that zakat is a "building-up" process. It functions like "economic glue" that has the ability to stick together different classes of the society with sense of love, care, and honor. Thus, its long-run implications are not to be seen in the context of faith alone but also in social, political, and economic context. The obligation of zakat implies that if a Muslim society has 100 percent regular prayer attendance in the Mosque (masjid), but the financial needs and expertise of the "have not's" is neglected, the case would be treated as matter of deliberate injustice. Since Islam guarantees economic opportunity to every citizen, irrespective of his/her personal financial capacity, any maltreatment in this regard would tantamount to violation of his/her due rights. According to Al-Mawardi, to promote justice by helping the weak is one of the fundamental responsibilities of the ruler (state in modern terminology). $\mathrm{He}$ writes:

"To dispense justice and
dispose of all litigation in
accordance with the
Shari'ah. He should
restrain the strong from
exploiting the weak and
help the weak in getting due
from the strong."(Mawardi
1375, p.11)

As mentioned above, Islam takes the moderate path between the economic doctrines of "Bourgeois Capitalism and Bolshevik Communism", therefore, on one hand, it promotes distribution on the basis of equity and, on other hand, it commands the "rich" to give some portion of their wealth in the form of zakat for those who are in need so that the whole system remains internally balanced (Muslehuddin 2009; Ausaf \& Azeem 2011).

\section{DISCOURAGING BEGGARY}

Beggary has become a menace in many societies. Even in many Muslim states, beggary is the most visible practice in the markets, streets, motor parks, filling stations, and outside religious places like masjids and shrines. In my personal observation, a person will generally beg only if he/she met one of the criteria: physical inability due to old age, sickness, or disability or inability to find a job due to economic factors or non-economic factors. Whatever the reason, in Islam, begging is a discoursed and unwanted attitude. In this connection, the Prophet is reported to have said:

\section{"Whoever begs from people so as to accumulate riches, he is asking for live coal (fire) from Hell, so let him ask for a lot or a little" (Ibn-e-Majah, Muhammad Bin Yazid (2011) Al- Sunan, Farid Book Stall, Lahore, V.1, P.478)}

The practical cure for the problem of begging is two-fold. The first step is providing suitable jobs for all those who can work. This is one of the responsibilities of the Islamic state towards its citizens. The second part of Islam's cure for begging is social insurance for those who have no income. This needs equal support from both the state as well as the civil society, including philanthropic associations. Such persons should be guaranteed a minimum standard of living or an income above the poverty line, as per the modern concept, suitable to a given Islamic society. Such an approach is clearly evident from the Prophetic period. It is reported that once a person came to Prophet and asked for financial help, Prophet asked him to bring a cup (that he had) to sell in the public for two dirhamone to buy food for the family and another one to buy an axe-head as an instrument (or capital) to get wood and sell it. Next, the Prophet did not want to see the man for 
ten days. After ten days the same person came back with ten dirham in his hand as his earning. On seeing such a major transformation in the economic behavior of that poor man, from "taker" to "giver", as result of meaningful and productive charity, the Prophet said:

"This is better for you than
the begging that comes as a
scar on your face on the
Day of Rising. Therefore,
begging is not permissible
except to one of three. A
destitute poor person, or a
person with overwhelming
debts, or a person who has
to pay ransom or to buy the
freedom for an accidental
homicide"

The methodology adopted by the Prophet in this case, implies that a Muslim must not ask for begging if he/she is able to earn, and such taking is not permissible except as a last resort. Moreover, it outlines that "charity" should not be given to sustain this trend, but rather to transform the society form "taking side" to "giving side". It also implies that through zakat funds, the unemployed labor could be provided with necessary tools, machinery, and capital for starting productive work (Abdullah \& Abdulquddos, 2013; Yusoff, 2008).

\section{WHAT ZAKAT HAS ACHIEVED}

After critically examining the literature, both theoretical and empirical, regarding zakat and its philanthropic role in promoting social justice and economic growth, the results almost appear negligible, except in few cases. It means, theoretically zakat has potential to do everything, but practically, it has not been able to do what it is expected to and reasons, obviously, are many. ${ }^{3}$ The

\footnotetext{
3 The researcher being a 'participant observer' studied this problem in Kashmir. Kashmir is a Muslim majority state of India. The level of
}

evidence from countries for which data are available highlights the fact that distribution of zakat in different countries is devoid of a uniform pattern. For example, in Turkey the most common category of zakat recipients are "needy" but who are in acquaintance with or relative to the distributing agency (Carkoglu, 2004). Indonesians gave zakat mainly to zakat-based charity organizations or directly to individuals who presumably are known to the zakat giver (Center for Languages and Cultures 2004, p. 8). In countries such as Malaysia, Saudi Arabia, and Pakistan, the overall structure of zakat is managed by the state. Thus, these countries stand as a reference point while examining the practical benefits of zakat proceeds. In all these three countries, there are evidences of widespread mismanagement, malfunction, and corruption as far as collection and distribution of zakat is concerned.

For example, in Malaysia, restrictive coverage and substantial evasion constrain the yield. Furthermore, the burden of zakat almost exclusively falls on rice growers, while most of them lie below the country's poverty line. Thus, zakat does not necessarily transfer resources to the poor in Malaysia, rather it may be transferring resources away from them (Kuran, 2004, p. 21-22). A detailed study of zakat collection of a village in the Malaysian state of Kedah suggests that the rate of compliance between 1977 and 1979 was only 15 percent, which means that majority of the farmers avoided their zakat obligation. Then, it resulted in disguising or under-declaring cultivated acreage and handing over spoiled or adulterated grain

religiosity among the people is comparatively good. The irony is, in this small piece of land, we see near about 100 religious organizations and all claiming 'major affiliation'. These organizations collect huge amounts of zakat at the end of every fiscal year but due to lack of management, efficiency, and transparency their progress is unknown. Even, today, hundreds of people including women, and young children are found begging outside busy public places like Masjids, Hospitals, markets and shrines. 
to the zakat collectors (Scott 1987; Ibrahim 2015).

In the case of Pakistan, there is widespread zakat evasion because a large chunk of the population does not trust the government's zakat collection and distribution policies. For example, the total amount donated to charity in Pakistan in 2000 was estimated to be Rs 70 billion (Aga Khan Development Network 2000) per annum whereas the total zakat collection amounted to only 4 billion, which signifies the low credibility attached to the government-run zakat system by the people of Pakistan. The zakat system in Pakistan has about one million beneficiaries, which indicates that only 10 percent of the total population is situated below the official poverty line. The government's own reports suggest that the state-administered system has had little impact on the reduction of inequality. The corruption, evasion, and maladministration of zakat in Pakistan is causing people to lose faith in the system (Kusuma \& Sukmana, 2010; Ibrahim, 2015; Abdullah \& Suhaib, 2011; Bello, 2009).

Although, many researchers have critically analyzed the system of zakat collection, but the analysis by Kuran, a Turkish scholar, is comparatively the most authentic one as far as the nature, approach, and methodology of his work are concerned. Kuran (2004), after examining the official records from different countries, concluded that decentralized voluntary zakat collection tends to be biased against poor people without proper connections and has little or no effect on poverty alleviation. He also examined the centralized systems, for example, in the case of Pakistan and Malaysia, and reported the same flaws. According to Kuran's analysis, the essential difference between the two modes lies neither in fairness nor in ability to reduce poverty. He writes

"It lies, rather, in the connections to which they

\begin{abstract}
confer value. Decentralized
zakat confers value to

economic connections,

especially ones based on

employment; state

administered zakat confers

value to political

connections, particularly

ones touching on religion.

Thus, under Malaysia's old

decentralized system the

surest way to obtain

regular zakat payment was

to work loyally for a

wealthy landlord; under the

current centralized system

it is to enroll in a religious

school or work for the zakat

office" (Kuran 2004 p. 26)
\end{abstract}

The critical evaluations made by Kuran (2004), Wahid et al. (2009), Rahman et al. (2012), Ramli et al. (2011), Ahmed et al. (2006) and many others lead us to conclude that zakat, as a practical philanthropic act, has not made a significant change in reducing the Muslim poverty graph and inequality gap till date.

\section{CONCLUSION}

The prevailing reality of the entire Muslim world, except for a few oil economies, is really miserable. Conditions such as poverty, illiteracy, malnutrition, lack of social justice, and class divisions are some of its prominent manifestations. The cause behind this "ugly composition" is not its social and economic conceptualization, but the failure of public authorities, NGO's, and religious organizations to prove its strength and applicability. In this backdrop, the paramount duty of Muslim intellectuals, politicians, economists, and policy makers is to transform the institution of zakat into a practical philanthropic movement that would promote the culture of cooperation and social justice. Consequently, it will enhance the process of economic growth and prosperity in the entire Muslim world. 
Muslim governments must establish advanced philanthropic organizations and give them whatever support they need. In a Muslim society, the practice of evasion of zakat does tantamount to promote corruption and under-development. Therefore, the efficient management of zakat, from collection to distribution level, under such a situation becomes a primary responsibility of the governments, civil societies, and every individual Muslim to contribute the due share so that the "weaker section" of society is strengthened and uplifted. I propose a dynamic philanthropic movement to transform the institution of zakat into a powerful symbolic unity within the Muslim world.

This symbolic unity, in return, will express Islam as strong, just, fair, and ethical community of believers-the Ummah. The philanthropic meaning of zakat is that it contributes to the creation of such a "model" community. Therefore, Muslims, as active philanthropists, have to raise upto to the challenges of the day and establish an organized system of economy from regional to global level.

In the case of personal administration of zakat, individual payers should consider members of their family first in discharging this important duty. That way, the role of zakat would be more profound and its impact will be experienced everywhere. The entire society will enjoy its blessings and every single individual will be free from crime and insanity. Allah says, "... whatever is paid as zakat for the sake of Allah shall be rewarded in manifolds".

\section{REFERENCES}

Abdullah, Suhaib, \& Abdul Quddus (2011). The Impact of Zakat on Social life of Muslim Society. Pakistan Journal of Islamic Research, Vol. 8, pp. 85-91

Aga Khan Development Network. (2000). The Conference on Indigenous Philanthropy. www.akdn.org/agency/philanthrop y/ingphillNTR.html.

Ahmad, Ausaf. (n.d). A Macro Model of Distribution in an Islamic Economy, Islamic Research and Training Institute, Islamic Development Bank

Al Sheikh, A. (1995). "Zakat", in Esposito, J. et al. eds. The Oxford Encyclopaedia of the Modern Islamic World. New York: Oxford University Press.

Ansari, Abdul Haseeb. (2011).Distributive Justice in Islam: An Expository Study of Zakah for Achieving a Sustainable Society. Australian Journal of Basic and Applied Sciences, 5(8): 383-393, 2011.

Ausaf and Azeem (2011). Ma'ashi Masail aur Qur'ani T;alimaat. Idarah Uloom Al-Quran, Aligarh, India.

Benthall, J. (1999). Financial Worship; the Quranic injunction to almsgiving. Journal of the Royal Anthropological Institute, Vol. 5, No. 1.

Bremer, Jennifer. (2013). Zakat and Economic Justice: Emerging International Models and their Relevance for Egypt, Takaful 2013 Third Annual Conference on Arab Philanthropy and Civic Engagement June 4-6, 2013 Tunis, Tunisia

Carkoglu, A. (2004). Philanthropy in Turkey. Istanbul: Tusev.

Center for Languages and Cultures. (2004). Philanthropy for Social Justice in Muslim Societies: Indonesian Case studies. Jakarta: Syarif Hidayatullah State Islamic University.

Dhar, Pranam. (2013). Zakat as a Measure of Social Justice in Islamic Finance : An Accountant's Overview, Journal of Emerging Economies and Islamic Research, Vol.1 No.1.

Dogarawa, A.B. (2003). Ethical Issues and Implementation of Islamic Policies for Poverty Eradication. in 
Dandago \& Tanko (eds) Conference Proceedings of 1 st National Conference on Ethical Issues in Accounting, Department of Accounting, Bayero University, Kano.

Dogarawa, A.B. (2006). Combating Poverty through Self-Reliance: The Islamic Approach. Journal of Business Administration, Vol. I, No. 1, Ahmadu Bello University, Zaria.

Dogarawa, A.B. (2008). Islamic Social Welfare and the Role of Zakah in the Family System. Online at http://mpra.ub.unimuenchen.de/23192/ MPRA Paper No. 23192, posted 10. June 2010 13:40 UTC.

Dogarawa, A.B. (2009). Poverty Alleviation through Zakah and Waqf Institutions: A Case for the Muslim Ummah in Ghana. Online at https://mpra.ub.unimuenchen.de/23191/ MPRA Paper No. 23191, posted 10. June 2010 13:38 UTC

Hairunnizam Wahid, Radiah Abdul Kader and Ahmad, Sanep. (na). Localization of zakat Distribution, Religiosity, Quality of Life and Attitude Change (perceptions zakah recipients in Malaysia), paper presented at the $13^{\text {th }}$ Malaysia Indonesia Conference on Economics, Management and Accounting 2012 p. 2-3

Hamidullah, M. (1993). The Emergence of Islam. Trans. by Afzal Iqbal. Islamabad: Islamic Research Institute.

Hasan, S. (2004). Islamic Philanthropy, Social Justice, and Development: Modern Challenges and Responses. Paper presented at the Sixth International Society for Third Sector Biennial Conference, Ryerson University, Toronto, Canada.

Hasan, Samiul. (2007). Islamic Concept Of Social Justice: Its Possible
Contribution To Ensuring

Harmony And Peaceful

Coexistence In A Globalized

World. Macquarie Law Journal, Vol. 7. pp. 168-183

Hassan, K. (2010). “An Integrated Poverty Alleviation Model Combining Zakat. Awqaf And Micro-Finance, Seventh International Conference - The Tawhidi Epistemology: Zakat and Waqf Economy, Bangi - Malaysia.

Hassan, Riaz. (2007). Giving and Gaining: Philanthropy and Social Justice in Muslim Societies. Lahore Journal of Policy Studies, Vol. 1, No. 1, pp. $25-35$

Hoque, et al. (2015). Poverty Alleviation By Zakah In A Transitional Economy: A Small Business Entrepreneurial Framework. Journal of Global Entrepreneurship Research, Vol. 5, No. 7

Kahf, M. (1989). Zakah: Unresolved Issues in the Contemporary Fiqh", Journal of Islamic Economics. International Islamic University of Malaysia, Kuala Lampur, Malaysia.

Kahf, M. (1997). The Performance of the Institution of Zakah in Theory and Practice. Paper Presented at the International Conference on Islamic Economics towards the 21st Century, Kuala Lumpur

Kuran, T. (2004). Islam and Mammon. Princeton: Princeton University Press

Kusuma, D.B.W., \& Sukmana, R. (2010). The Power of Zakah in Poverty Alleviation, paper presented at the Seventh International Conference - The Tawhidi Epistemology: Zakat and Waqf Economy, Bangi, available at: www.ukm.my/ (accessed 12 December, 2015).

Laghari, J. (15 June, 2013). The Express Tribune, available at: http://tribune.com.pk/story/563435 /gdp-40pc-of-muslimstates- 
population-fall-below-poverty-line (accessed 12 November 2015).

Mathews, R. and Tlemsani, I. (2003). Zakat and Social Capital: Parallels between Islam and the West (draft). Centre for International Business Policy, Surrey.

Mawdudi, S. (1975). The Economic Problem of Man and Its Islamic Solution. Lahore: Islamic

Mohsin, Magda Ismail A. (2013). Potential of Zakat in Eliminating Riba and Eradicating Poverty in Muslim Countries. EJBM-Special Issue: Islamic Management and Business, Vol.5 No.11 2013.

Muslehuddin, Mohammad. (2009). Economics and Islam. Markazi Muktaba Publishers, New Dehli.

Pew Research Centre (2014). The future of the global Muslim population. Available at: http://www.pewforum.org/2011/ 01/27/the-future-of-the-globalmuslim-population/ (accessed 19 November 2015).

Qaradawi, Y. (1999). Fiqh az-Zakah (Arabic), Dar al-Taqwa LTD, London. Sadeq, A.M. (1989): "Distribution of Wealth through Transfer Payment", Hamdard Islamicus, Vol. 12 No 1 Sadeq, A.M. (1990): Economic Development in Islam, Pelanduk Publication, Kuala Lampur, Malaysia.

Shehata, S.I. (1989). Limitations on the use of Zakah Funds in Financing the Socio- Economic

Infrastructure of Society. Imtiazi et al (eds) Management of Zakah in Modern Muslim Society, Islamic Institute of Research and Training, Jeddah, Saudi Arabia

Siddiqi, M. N. (1996). Role of the State in the Economy - An Islamic Perspective. The Islamic Foundation, UK.

The Nation (2011). Available at: http://www.nation.com.pk/pakista n-news-newspaper-daily-englishonline/business/25-

World Bank (2010). Poverty profile in Muslim world, Accessed May 11, 2015, from http://www.worldbank.org

Yousuf and Desumite. (2013). Zakat Administration, Distribution and Economic Growth: A study in the Federal Territory of Malaysia. Lap Lamber academic publishing, Germany.

Yusoff, Wan Sulaiman bin Wan. (2008). Modern Approach of Zakat as an Economic and Social Instrument for Poverty Alleviation and Stability of Ummah. Jurnal Ekonomi dan Studi Pembangunan, Vol. 9, No. 1, pp.

Bilal Ahmad Malik, Centre of Central Asian Studies University of Kashmir Pakistan gazibilal@ymail.com 